INVITED REVIEW ARTICLE

\title{
肺がん診療における免疫関連有害事象の管理
}

\author{
三浦 理 1 -磯貝佐知子 $2 \cdot$ 吉野真樹 $3 \cdot$ 馬場順子 $1 \cdot$ 梶原大季 $1 \cdot$ \\ 小山建一 $1 \cdot$ 竹之内辰也 $4 \cdot$ 谷 長行 $1 \cdot$ 田中洋史 1
}

\section{Management of Adverse Events Induced by Immune Checkpoint Inhibitors in Lung Cancer Treatment}

Satoru Miura1; Sachiko Isogai2; Masaki Yoshino3; Junko Baba1; Takasue Kajiwara1;

Kenichi Koyama1; Tatsuya Takenouchi4; Nagayuki Tani1; Hiroshi Tanaka ${ }^{1}$

${ }^{1}$ Department of Internal Medicine, ${ }^{2}$ Pharmaceutical Division, ${ }^{3}$ Nursing Division, ${ }^{4}$ Department of Dermatology, Niigata Cancer Center Hospital, Japan.

ABSTRACT - Progress in the field of cancer immunotherapy with programmed cell death protein $1 /$ programmed death-ligand 1 (PD-1/PD-L1) checkpoint inhibitors has profoundly influenced the treatment of lung cancer. The survival benefits of these agents compared with those of standard treatments have been demonstrated in patients in first and second lines as well as in maintenance settings after chemoradiotherapy. However, while the safety profile and feasibility are generally favorable, these agents are also associated with immune-related adverse events (irAEs). The incidence of irAEs is relatively rare, but patients occasionally develop serious adverse events that can be fatal. When irAEs will occur and the organs that will be affected cannot be predicted, and appropriate methods for managing irAEs have not been established. Furthermore, most physicians are not familiar with the clinical management of irAEs. In order to overcome these problems, investigations to predict biomarkers of irAEs and the application of multidisciplinary team approaches are being attempted. These trials may lead to the early detection and management of irAEs through patient education. This review summarizes the current data and consensus concerning the management of irAEs induced by immunotherapy in lung cancer treatments.

(JJLC. 2019;59:231-237)

KEY WORDS — Immune checkpoint inhibitor, Immune-related adverse event, Lung cancer, Multidisciplinary team approach

Corresponding author: Satoru Miura.

要旨—PD-1/PD-L1 阻害剤に代表される免疫チェッ クポイント阻害剂を用いるがん免疫療法の開発は, 肺が んの治療に大きな影響を与えた。 これらの薬剤は, 非小 細胞肺がん患者の初回治療, 2 次治療さらには化学放射 線治療後の維持療法において, 標準治療と比較して生存 期間延長効果が示されている. 安全性と忍容性は非常に 良好だが,これらの薬剤は免疫関連有害事象（irAE）を 起こし得る. その頻度は稀であるものの, 時に致死的と なる重篤な事例に直面することがある．さらに ir AE は いつ, どの蔵器が罹患するかを予測することができず,
未だ適切な管理方法は確立していない。未だ多くの医師 は, irAEの管理に精通しているとは言いがたい状況であ る。これらの問題を克服するために, ir AE 発症のバイオ マーカーを予測する検討や, 集学的チームアプローチに よる管理が試みられつつある。これらの検討は, 患者教 育を通した irAEの早期発見, 管理に繋がる可能性があ る.この総説では, 肺がん治療における irAEに関わる現 在のデータとコンセンサスをまとめた.

索引用語——免疫チェックポイント阻害剂, 免疫関連有 害事象, 肺がん, 多職種チーム医療 


\section{はじめに}

非小細胞肺がん (non-small cell lung cancer : NSCLC) 治療に打いて大きなパラダイムシフトをもたらした免疫 チェックポイント阻害片 (immune checkpoint inhibitor：ICI）は，今や多くのがん腫に打いて適応を取得し， がん治療に関わる医師のみならず看護師，薬荗師をはじ めとするスタッフにも知識の習熟が求められている. 現 在 NSCLC に適応を取得しているICI は PD-1 阻害片と PD-L1 阻害剤であり, 疲弊した T 細胞を再活性化するこ とで抗腫瘍効果を発揮する。また，それと同時に免疫関 連有害事象 (immune-related adverse event: irAE) と呼 ばれる特殊な有害事象も惹起し得る。その頻度は少ない ものの, 発生する時期, 部位, 重症度を予測することは 困難であり，その対策にはチームによる介入が求められ ているが，それぞれの対策について前向きな検討はほと んどなく，その具体的な対策法はまだ確立したとは言い がたい.この総説では, 肺がん治療に扔ける irAEに関わ る現在のデータとコンセンサスをまとめた.

\section{免疫関連有害事象の起こる機序とその予測}

免疫チェックポイントは本来, 人体に扔いて免疫学的 なホメオスターシスを維持する役割を担っている. CTLA-4, PD-1 をノックアウトしたマウスはリンパ増殖 性疾患や，ループス関節炎・腎炎，心筋炎で死に至るこ とが示されて扔り, 生体内で正常な免疫を維持するため に免疫チェックポイントは重要な役割を果たしているこ とが司見える。 ${ }^{1,2} \mathrm{ICI}$ の投与により, 疲弊 $\mathrm{T}$ 細胞の再活性 化とともに，これらのホメオスターシスに何らかの影響 を与え, irAE は発症すると考元られる. irAE の起こる機 序は完全に解明されていないが, いくつかの有害事象で はその発症機序を示唆する報告がなされている. ${ }^{3}$ 抗 CTLA-4 抗体と抗 PD-1 抗体併用療法後に発症した劇症 型心筋炎では T 細胞の著明な浸潤が心筋内に認められ ており， T細胞による直接障害がその機序として想定さ れている. ${ }^{4}$ また, 甲状腺機能障害は甲状腺自己抗体存在 下で発症頻度が上がることから, PD-1/PD-L1 阻害剤が 何らかの形で抗体介在性の免疫反応を惹起することがそ の機序と考えられている. ${ }^{5}$ このほか, 大腸炎はサイトカ インによる影響が強いなどそれぞれの irAE 毎に発症機 序は異なることが想定される，今後，それぞれの機序に 基づくirAEの治療法が確立することが期待される.

\section{免疫関連有害事象の予測因子}

投与症例にどの irAE が出現するのかの予測について は，いくつかの検討が報告されつつある，治療前に自己 抗体陽性の症例では irAE が 3.25 倍出やすいことが, 後
方視的解析で明らかにされている. ${ }^{6}$ 特に甲状腺自己抗 体陽性例では, 甲状腺機能障害の出現割合が高い（陽性 $20 \%$ vs. 陰性 1\%). 甲状腺自己抗体は成人女性に扔いて 10 人に 1 人が陽性であるとされており，陽性者において は甲状腺機能障害出現に注意して観察することが勧めら れる。また, 腸内細菌環境が免疫に影響を与え, 特定の 腸内細菌が治療効果と同様に有害事象の発症に打いても 予測因子となり得る可能性があることが報告されてい る. 7.8 腸内細菌環境は人種や生活環境によっても異なる 可能性があり, 我が国の臨床に応用できるかどうかは今 後の検討が必要であるが, 興味深い知見である.

\section{免疫関連有害事象の発症時期}

それぞれの irAE 毎に発症時期は異なり, 皮疹や消化 器毒性は早い傾向がある一方で, 内分泌系有害事象や腎 毒性はやや遅れて発現する傾向がある. 9 しかし, その傾 向は症例毎で異なり, 自験例ではあるが, 投与後 1 年以 上経過してから 1 型糖尿病を突然発症するなどのケース も経験される. 長期投与となる症例では患者はもちろん, 担当医や医療スタッフも irAE に対する意識が低下して くるため注意が必要である.

\section{免疫関連有害事象と抗腫瘍効果}

irAE は本来がん細胞（非自己）に向くべき免疫が自分 の正常な細胞（自己）に向くことにより起こると解釈さ れるため, irAE の発症が抗腫瘍効果の裏返しであろうこ とは想像に難くない. NSCLCを対象とした前向きコ ホート研究や後方視的解析において, irAE の発症は治療 効果と相関することが複数報告されている.10,11 irAEの 発症を抢それるのではなく, 発症した症例では抗腫瘍効 果も高い可能性を考虑して, うまく早期発見から適切な 対応へと慗げることで ICI の効果を最大限に引き出す工 夫が肝要である.

\section{免疫学的有害事象の治療}

irAE の治療はその有害事象により異なるが, ICI の延 期・休止または副腎皮質ステロイド剤による短期的な免 疫抑制治療がメインとなる。一般には Grade 2 であれば ICI の休薬で経過観察し改善の有無を確認, 改善がなけ ればプレドニゾロン換算 $0.5 \sim 1.0 \mathrm{mg} / \mathrm{kg}$ の治療導入を, Grade 3 以上であれば ICI 休薬のうえでプレドニゾロン 換算 $1.0 \sim 2.0 \mathrm{mg} / \mathrm{kg}$ の治療導入を検討する場合が多い （詳細は各治療薬の適正使用ガイドラインや ASCO ガイ ドライン, 12 日本臨床腫瘍学会から発行されるがん免疫 療法ガイドラインなどを参照のこと).ステロイド治療抵 抗例にはさらなる免疫抑制剂治療が推奨される.しかし, 自己免疫性肝障害に対するミコフェノール酸モフェチル 
や大腸炎に対するインフリキシマブなどそれぞれの有害 事象により推奨される免疫抑制剤が異なり,さらにこれ らの薬剤は我が国では現時点で保険適応がないことには 注意が必要である.PD-1/PD-L1 阻害剤によって引き起 こされる致死的な irAE は肺蔵炎 $(35 \%)$, 肝炎 $(22 \%)$, 大腸炎 (17\%), 神経系障害 (15\%), 心筋炎 (8\%) と報告 されており,これらの有害事象に対しては特に慎重な対 応が求められる. 13

\section{主たる免疫関連有害事象についての各論}

\section{(1)肺障害（interstitial lung disease : ILD）}

PD-1/PD-L1 阻害剤による ILD の頻度は報告によって も差があり概ね $10 \%$ 未満程度とされているが, 他がん腫 と比較して NSCLCで多い. 14,15 さらには EGFR チロシ ンキナーゼ阻害剤による薬剤性 ILD と同様に, 我が国で は海外と比較して ILD の頻度が高い可能性が示唆され ており, 特に注意が必要である. 16 PD-1/PD-L1 阻害剂に よる ILD は他の薬剤性 ILD と比較して休薬や副腎皮質 ステロイド剤の介入で改善するケースがほとんどである が, 約 1 割の患者では致死的になり得る. 高用量の副腎 皮質ステロイド剤などの免疫抑制剤で一時的に回復する も, 減量時に再燃し, 致死的となった症例も報告されて いるため, 免疫抑制治療の漸減には注意が必要である. 17

PD-1/PD-L1 阻害剤による ILD の画像所見は cryptogenic organizing pneumonia (COP) like type (19\%), ground glass opacities (GGO) type (37\%), interstitial pneumonia like type (7\%), hypersensitivity type (22\%), 分類不能型 (15\%) と非常に多彩である. NSCLCにおい ては他のがん腫と比較して COP type が多く，副腎皮質 ステロイド剤の介入を要する場合が多いとされる. 14 我 が国のニボルマブ市販後調查（中間解析）における ILD 解析では, 発生頻度は $5.8 \%$, 発症までの期間中央值は 40 日（範囲：2２46 日）であり，75歳以上，背景肺の異常 陰影, 2 次治療の症例が多変量解析で発症のリスク因子 として抽出された. 18 また, Grade 3 以上の重篤例は $3.4 \%$, 致死例は $0.7 \%$ と報告され, 画像パターンでは急性 間質性肺炎様（acute interstitial pneumonia：AIP）パ ターンが $68.2 \%$ と最も致死例が多く, COP パターンは $9.8 \%$ であった. 19 致死的となる ILDのリスク因子は AIP パターン, 男性, $\mathrm{CRP}$ 上昇 $(5 \mathrm{mg} / \mathrm{dl}$ 以上) が抽出 された。これらは中間報告であり，全例の解析を含めた 詳細な報告が待たれる。

ILD の治療は ICI の投与休止, さらには副腎皮質ステ ロイド剂の投与が基本である. ${ }^{12}$ Grade 2 , すなわち症状 を伴う肺陰影が出現した際には, ICIを休止するととも に感染症を除外したうえで副腎皮質ステロイド剤の投与 を検討する．ステロイドの投与量に関しては前向きの検
討はないものの, 海外のガイドラインなどではプレドニ ゾロン換算で $1 \sim 2 \mathrm{mg} / \mathrm{kg} / \mathrm{day}$ が推奨されている. そし て漸減は 5〜 $10 \mathrm{mg}$ 週を 4〜6 週かけて行うとされてい るが, 前述のように再燃のリスクがあることから慎重に 行う. Grade 3 以上の呼吸不全を伴う ILD が発現した場 合にはすみやかにICI の投与を中止し, エンピリックな 抗菌薬治療とともにステロイド投与を積極的に検討す る. 経験的に大量ステロイド療法（ステロイドパルス療 法）が選択されることが我が国では多いが, 前向きな工 ビデンスはない. ILD 改善後の PD-1 阻害剤再投与に関 しては, 12 例の解析において Grade 1 であれば再燃は 11\%（1/9）に留まるが, Grade 2 の場合には 67\%（2/3） で再燃すると報告されている. 14 再燃例もステロイドの 再導入により改善が得られているものの, 再投与につい ては慎重に行うべきである.

\section{(2)甲状腺機能障害}

甲状腺機能障害は NSCLC の PD-1 阻害剂投与例の約 $10 \%$ 弱の症例で発現すると報告されており, 比較的頻度 の高い irAEであり，その発症には甲状腺自己抗体が関 与している可能性が高い. 5 我が国のレトロスペクティ ブな検討では自己抗体陰性例では $2 \%$ の発現であった一 方で, 陽性例では $40 \%$ で甲状腺機能障害が認められてい た. 6 甲状腺機能のモニタリングは月に 1 回程度 TSH と $\mathrm{fT} 4$ で実施することが推奨されている. $12 \mathrm{fT} 3$ は慢性消 耗性疾患において異常值を示しやすいため, 進行期担が ん患者においてはモニタリングする意義は低いと考えら れる. 病型としては甲状腺機能充進症から低下症に移行 するパターンと, 緩徐に低下症に至るパターンが多い. 前者の場合は $\beta$ ブロッカーなどで充進症症状を抑えな がら, 低下症に移行後 TSH $10 \mathrm{IU} / \mathrm{ml}$ 以上を示した段階 で甲状腺ホルモンの補充療法を行う. 後者の場合には, 症状の有無を確認しつつ, TSH の動きを見ながら補充療 法のタイミングを見ていく. 甲状腺ホルモン補充の際に は，副腎クリーゼのリスクを考慮して副腎機能をチェッ クしたうえで, 必要に応じてコルチゾールの補充も検討 する. ICI の投与は症状がある場合（Grade 2) には休止 するが, 症状がない場合 (Grade 1) にはそのまま継続投 与することが一般的である。甲状腺機能障害が発現した 症例は, 予後が良いことが示唆されており, 自己抗体陽 性例でも投与はためらうことなく, 慎重なモニタリング 下に PD-1/PD-L1 阻害剤投与を検討すべきである. 5

\section{(3) 1 型糖尿病}

ICI による自己免疫性の糖尿病の発症には, 膵 $\beta$ 細胞 に対する自己反応性 $\mathrm{T}$ 細胞による障害や GAD65 抗体 を介する機序が示唆されているが, 未だその詳細は解明 されていない. 20 その頻度は稀であるものの, 急激な経 過をたどりケトアシドーシスなどの致死的かつ重篤な状 
態で発見される可能性があることから, 臨床的に重要な $\operatorname{irAE}$ である。一般に 1 型糖尿病は「急性発症」「劇症型」 「緩徐進行」の 3 つの病型に分類され, PD-1/PD-L1 阻害 剤投与後の 1 型糖尿病は劇症 1 型糖尿病の基準を満たす 場合が多いとされる. 発症の予測は困難であるが, 1 型糖 尿病発症例の 4 例中 3 例で抗 GAD 抗体が陽性であった との報告もあり, そのような症例は比較的早期の発症が 懸念される. 21,222 型糖尿病と診断されている症例では, 緩徐進行型 1 型糖尿病のスクリーニングのため抗 GAD 抗体の投与前評価を行うことも方法の 1 つと考えられ る. 発症時期は予測がつかず, 症状も倦㤐感や口渇感な ど非特異的なものが多いため, チームによる患者教育に 加え, 患者の自己管理が早期発見には必須である. 適切 なスクリーニング法は確立していないが, 新潟県立がん センター新潟病院では, 患者自身によるテステープ チェックを推奨しており，ケトアシドーシスに至った 1 型糖尿病症例は現時点で皆無である。日本糖尿病学会は PD-1/PD-L1 阻害剂投与前, および投与開始後来院日毎 に血糖值の測定と高血糖症状の有無の問診を推奨してい る. 治療は症状発現後数日でインスリン分泌が枯渇する 場合がほとんどであり，早期発見であってもすみやかに 入院対応としてインスリン治療を導入することが勧めら れる. 一方で, 入院時にインスリン分泌が残存していて も, 数週〜数ヶ月の経過で緩徐に分泌が枯渇する症例も 当院では経験しており, 慎重な経過観察は意ってはなら ない.

\section{(4)大腸炎}

大腸炎は比較的頻度の高い irAEとして知られている が, 抗 CTLA-4 抗体が多く用いられる悪性黒色腫でその 頻度は多く, PD-1/PD-L1 阻害剤を用いる場合が多い NSCLC ではそれほど頻度は高くない. 23 しかし, 時に重 篤になる症例も経験されるため, その対応には習熟して おく必要がある。適切なスクリーニング法は確立してい ないが，下痢発症時に安易にロペラミドなどの止痢薬で 対応することで診断が遅れると重篤化すると言われてお り，下痢が発症した場合には慎重な対応が求められる。

Grade 2 (ベースラインと比較して 4 6 回の下痢回数の 増加）以上の下痢を認めた場合には, 便培養や CD トキシ ンなどの検査のほか, 腹部骨盤腔 $\mathrm{CT}$ や大腸鏡などの積 極的な実施により鑑別, 確定診断を行い, 副腎皮質ステ ロイド剤による治療を検討する。ステロイドによる治療 抵抗例にはインフリキシマブ $5 \mathrm{mg} / \mathrm{kg}$ による治療を併 用することが, 海外のガイドラインでは推奨されてい る. 12

\section{(5)心筋炎}

自己免疫性心筋炎は稀ではあるが最も致死率の高い $\operatorname{irAE}$ として報告されており, 胸痛や倦㤐感などの鑑別疾
患として頭に入れておく必要がある.13 心筋炎では細胞 障害性 $\mathrm{T}$ 細胞の浸潤が心笳内に認められることから, 免 疫細胞による直接的な心筋傷害がその病態に強く影響し ていると考えられる. 4 治療は副腎皮質ステロイド剤を 含む免疫抑制療法や大量免疫グロブリン療法が試みられ る. 循環動態が不安定な場合には, 急性期を乗り切るた めに高次医療機関の ICUにおける全身管理も積極的に 検討することが必要であり, 病院間の連携も確認してお く必要がある.

\section{(6)肝障害}

PD-1/PD-L1 阻害剂による肝障害の頻度は 3〜10\%, 発 症時期中央值は 8 12 週と報告されている. ${ }^{24}$ 肝障害は 肝転移の悪化や併用薬などでも起こり得るため, その鑑 別が重要となる. 治療は他の irAE と同様に ICI の休薬 と副腎皮質ステロイド剤の投与となるが, 抵抗例にはミ コフェノール酸モフェチルやアザチオプリンが提案され ている.12 インフリキシマブはそれ自体で肝障害が惹起 される可能性があるため, 推奨されない.

\section{(7)腎炎}

PD-1/PD-L1 経路は腎臓のホメオスターシスの維持に 重要な役割を果たしており, PD-1 ノックアウトマウスに おいては心筋炎などと同時に糸球体腎炎を発症する. ${ }^{2}$ ICI による急性腎障害（acute kidney injury：AKI）の頻 度は $2.2 \%$ で, 病型の多くは急性尿細管性間質性腎炎であ り, 人工透析に至るのは $0.6 \%$ とされている. ${ }^{25,26}$ 治療は 副腎皮質ステロイド剤による治療が基本であり, 血清ク レアチニン $2.0 \mathrm{mg} / \mathrm{dl}$ 以上では積極的な治療適応となる $(1.0 \sim 2.0 \mathrm{mg} / \mathrm{kg}) .{ }^{12} \mathrm{PD}-1 / \mathrm{PD}-\mathrm{L} 1$ 阻害剂単独投与例に おける腎炎発症頻度はそれほど高くないものの, プラチ ナ製剤+ペメトレキセド+ペムブロリズマブ療法に AKI の発症が多かった $(5.2 \%)$ ことから注目を浴びつつ ある. 27 腎炎の発現機序やその詳細についてのさらなる 検討が必要と考えられる。

\section{免疫療法サポートチーム}

2015 年 12 月に NSCLC にニボルマブが承認されて以 降, irAEの対策のために各病院で多くのチーム医療に関 する試みがなされ, ir AE の患者教育を通した早期発見に 有用であることが示唆されている. 28 当院でも免疫療法 サポートチーム (immunotherapy Support team In Niigata Cancer center : iSINC) を 2015 年 12 月より立ち上 げ，現在に至っている. 当院における iSINC のチームコ ンセプトは以下の 3 つである (Figure 1).

(1)早期発見のための “眼”を養う：前述したように irAEの発症はいつどこで起こるかわからない. わかりや すい患者説明文書や注意喚起シートなどを用いて, 患者 のセルフマネジメントを促す患者教育を行うシステム作 


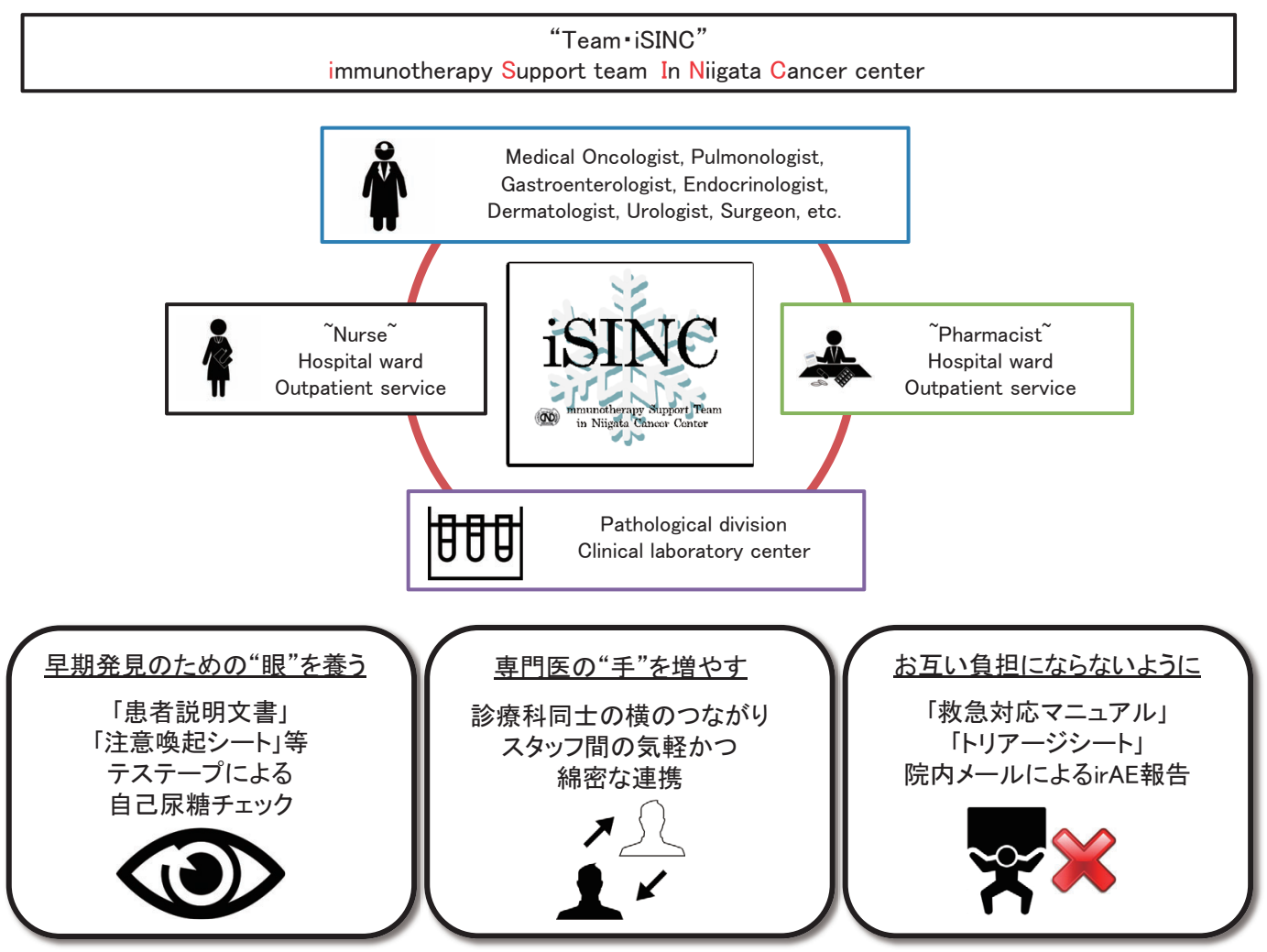

Figure 1. Summary of the multidisciplinary support team approach to immunotherapy.

りを行った。また，医師の他にも看護師，薬剤師など多 くの医療者の眼を通すことで早期発見を心がけることに も繋がると考えている.

(2)専門医の“手”を増やす：多彩な有害事象に対応す るために多彩な診療科と横のつながりを作り，コンサル トのハードルを下げる必要がある.

(3)互い負担にならない：当院ではなかなか毎週チー ムとして集まるのが難しく, 発症症例の検討, 知識の周 知徹底も進まない。 また，救急外来などでは専門外の医 師が対応せざるを得ない場合も多い。そこで患者もス タッフも安心して使用できる環境作りを目指して，救急 外来でのトリアージシート, 救急対応マニュアルを整備 した。また, ir AE 発症時には事務局を通して院内メール での周知徹底を行うことで, 使用経験が少ない医師でも $\operatorname{irAE}$ の症例経過, 転帰を経験できるようなシステムを構 築した。

ICI による irAE 対策はもはや特別なものではなく, 日 常診療で通常行われるべき診療の 1 つとなっている．治 療が多様化するなかで, 担当の医師だけですべてを管理, 指導することは極めて困難であり, 他科の医師, 看護師, 薬剂師，検査技師を含むチームで患者さんを支えること が当たり前の時代が来ている，マンパワーや診療科の壁 など多くの問題があることが多いが, 安心して患者さん
に ICI を提供するにはチーム体制の構築が必須の状況と なっている．肺がん診療を担う施設はその施設の状況な どに合わせた協力体制を構築していただければ幸いであ る。

\section{今後の展望}

他がん腫への適応拡大も顕著となっている一方で, 2018 年末から PS 良好の進行期 NSCLCにおいては, プ ラチナ併用療法と PD-1/PD-L1 阻害剂の併用療法が初回 治療の標準治療となり, 新たな時代が NSCLC の治療に 訪れている. 27 さらには進展型小細胞肺がんの初回治療 においてもプラチナ併用療法と PD-L1 阻害剤の併用療 法が承認される見込みであり, 肺がんのほとんどの症例, それも初回治療などの早い時期で ICI が投与されること になると予想される。ILDや腎炎はそれぞれの単剤療法 よりも多く発現する可能性が示唆されており，また肝障 害が起こった場合に, 両方の薬剤を休薬すべきか, ステ ロイド導入で改善した場合どちらの薬剤を再開すべきか など，臨床的には難しい問題がまだまだ残存しており， 今後もさらなる議論が必要である.

本論文内容に関連する著者の利益相反 : 三浦＼cjkstart理［講演料な ど]中外製薬，アストラゼネカ，イーライリリー, MSD, ベー 
リンガーインゲルハイム, 竹之内辰也[ 講演料など] 小野薬品, ブリストルマイヤーズスクイブ, 田中洋史 [講演料など] 中外 製薬株式会社, アストラゼネカ株式会社, ブリストルマイヤー ズスクイブ株式会社 [委受託研究 (治験等) ] 小野薬品工業株 式会社, MSD 株式会社

\section{REFERENCES}

1. Waterhouse P, Penninger JM, Timms E, Wakeham A, Shahinian A, Lee KP, et al. Lymphoproliferative disorders with early lethality in mice deficient in Ctla-4. Science. 1995;270:985-988.

2. Nishimura H, Nose M, Hiai H, Minato N, Honjo T. Development of lupus-like autoimmune diseases by disruption of the PD-1 gene encoding an ITIM motif-carrying immunoreceptor. Immunity. 1999;11:141-151.

3. Postow MA, Sidlow R, Hellmann MD. Immune-Related Adverse Events Associated with Immune Checkpoint Blockade. N Engl J Med. 2018;378:158-168.

4. Johnson DB, Balko JM, Compton ML, Chalkias S, Gorham J, Xu Y, et al. Fulminant Myocarditis with Combination Immune Checkpoint Blockade. $N$ Engl J Med. 2016;375:1749-1755.

5. Osorio JC, Ni A, Chaft JE, Pollina R, Kasler MK, Stephens D, et al. Antibody-mediated thyroid dysfunction during T-cell checkpoint blockade in patients with non-small-cell lung cancer. Ann Oncol. 2017;28:583-589.

6. Toi Y, Sugawara S, Sugisaka J, Ono H, Kawashima Y, Aiba T, et al. Profiling Preexisting Antibodies in Patients Treated With Anti-PD-1 Therapy for Advanced NonSmall Cell Lung Cancer. JAMA Oncol. 2018 [Epub ahead of print] doi: 10.1001/jamaoncol.2018.5860.

7. Sivan A, Corrales L, Hubert N, Williams JB, Aquino-Michaels K, Earley ZM, et al. Commensal Bifidobacterium promotes antitumor immunity and facilitates anti-PD-L1 efficacy. Science. 2015;350:1084-1089.

8. Chaput N, Lepage P, Coutzac C, Soularue E, Le Roux K, Monot $\mathrm{C}$, et al. Baseline gut microbiota predicts clinical response and colitis in metastatic melanoma patients treated with ipilimumab. Ann Oncol. 2017;28:1368-1379.

9. Weber JS, Hodi FS, Wolchok JD, Topalian SL, Schadendorf D, Larkin J, et al. Safety Profile of Nivolumab Monotherapy: A Pooled Analysis of Patients With Advanced Melanoma. J Clin Oncol. 2017;35:785-792.

10. Teraoka S, Fujimoto D, Morimoto T, Kawachi H, Ito M, Sato Y, et al. Early Immune-Related Adverse Events and Association with Outcome in Advanced Non-Small Cell Lung Cancer Patients Treated with Nivolumab: A Prospective Cohort Study. J Thorac Oncol. 2017;12:17981805.

11. Haratani K, Hayashi H, Chiba Y, Kudo K, Yonesaka K, Kato R, et al. Association of Immune-Related Adverse Events With Nivolumab Efficacy in Non-Small-Cell Lung Cancer. JAMA Oncol. 2018;4:374-378.

12. Brahmer JR, Lacchetti C, Schneider BJ, Atkins MB, Brassil KJ, Caterino JM, et al. Management of ImmuneRelated Adverse Events in Patients Treated With Immune Checkpoint Inhibitor Therapy: American Society of Clinical Oncology Clinical Practice Guideline. J Clin Oncol. 2018;36:1714-1768.

13. Wang DY, Salem JE, Cohen JV, Chandra S, Menzer C, Ye F, et al. Fatal Toxic Effects Associated With Immune Checkpoint Inhibitors: A Systematic Review and Metaanalysis. JAMA Oncol. 2018;4:1721-1728.

14. Naidoo J, Wang X, Woo KM, Iyriboz T, Halpenny D, Cunningham J, et al. Pneumonitis in Patients Treated With Anti-Programmed Death-1/Programmed Death Ligand 1 Therapy. J Clin Oncol. 2017;35:709-717.

15. Nishino M, Giobbie-Hurder A, Hatabu H, Ramaiya NH, Hodi FS. Incidence of Programmed Cell Death 1 Inhibitor-Related Pneumonitis in Patients With Advanced Cancer: A Systematic Review and Meta-analysis. JAMA Oncol. 2016;2:1607-1616.

16. Vansteenkiste J. Nivolumab for NSCLC in Japanese patients: similar benefits, but beware of pneumonitis. ESMO Open. 2017;2(Suppl 1):e000119.

17. Nishino M, Chambers ES, Chong CR, Ramaiya NH, Gray SW, Marcoux JP, et al. Anti-PD-1 Inhibitor-Related Pneumonitis in Non-Small Cell Lung Cancer. Cancer Immunol Res. 2016;4:289-293.

18. Kenmotsu H, Sakai F, Kato T, Kusumoto M, Baba T, Kuwano K, et al. Nivolumab-induced interstitial lung disease (ILD) in Japanese patients with non-small cell lung cancer: A study on risk factors using interim results of post-marketing all-case surveillance. J Clin Oncol. 2017;35 (Suppl):9078-9078.

19. Kato T, Sakai F, Baba T, Kusumoto M, Kenmotsu H, Sugiura $\mathrm{H}$, et al. Nivolumab-induced interstitial lung disease (ILD) in Japanese patients with non-small cell lung cancer: A study on risk factors for fatal outcome. J Clin Oncol. 2017;35(Suppl):9077-9077.

20. Hughes J, Vudattu N, Sznol M, Gettinger S, Kluger H, Lupsa B, et al. Precipitation of autoimmune diabetes with anti-PD-1 immunotherapy. Diabetes Care. 2015;38: e55-e57.

21. Godwin JL, Jaggi S, Sirisena I, Sharda P, Rao AD, Mehra $\mathrm{R}$, et al. Nivolumab-induced autoimmune diabetes mellitus presenting as diabetic ketoacidosis in a patient with metastatic lung cancer. J Immunother Cancer. 2017;5:40.

22. Matsuura N, Koh G, Konishi C, Minamino S, Takahara Y, Harada $\mathrm{H}$, et al. Fulminant onset of insulin-dependent diabetes with positive anti-GAD antibody titers during treatment with nivolumab in a patient with NSCLC. Cancer Immunol Immunother. 2018;67:1417-1424.

23. Khoja L, Day D, Wei-Wu Chen T, Siu LL, Hansen AR. Tumour- and class-specific patterns of immune-related adverse events of immune checkpoint inhibitors: a systematic review. Ann Oncol. 2017;28:2377-2385.

24. Karamchandani DM, Chetty R. Immune checkpoint inhibitor-induced gastrointestinal and hepatic injury: pathologists' perspective. J Clin Pathol. 2018;71:665-671.

25. Wanchoo R, Karam S, Uppal NN, Barta VS, Deray G, Devoe C, et al. Adverse Renal Effects of Immune Checkpoint Inhibitors: A Narrative Review. Am J Nephrol. 2017; 45:160-169.

26. Cortazar FB, Marrone KA, Troxell ML, Ralto KM, Hoenig MP, Brahmer JR, et al. Clinicopathological fea- 
tures of acute kidney injury associated with immune checkpoint inhibitors. Kidney Int. 2016;90:638-647.

27. Gandhi L, Rodríguez-Abreu D, Gadgeel S, Esteban E, Felip E, De Angelis F, et al. Pembrolizumab plus Chemotherapy in Metastatic Non-Small-Cell Lung Cancer. $N$
Engl J Med. 2018;378:2078-2092.

28. Naidoo J, Cappelli L, Lipson E, Forde PM, Sharfman WH, Zhang J, et al. A multidisciplinary toxicity team for cancer immunotherapy-related adverse events. J Clin Oncol. 2018;36(Suppl):6538-6538. 